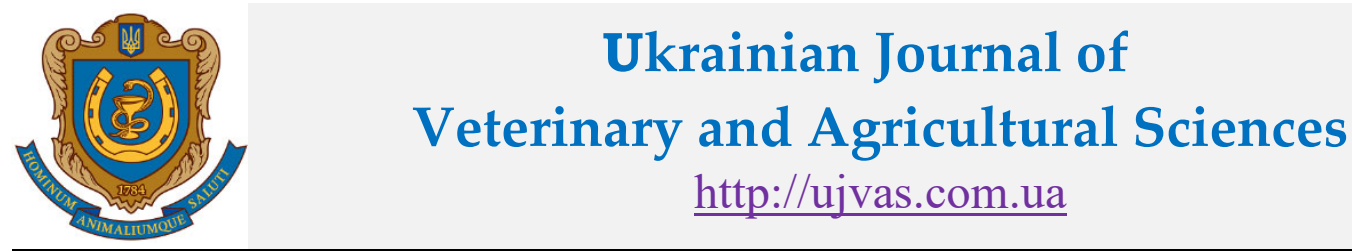

Stepan Gzhytskyi National University of Veterinary Medicine and Biotechnologies Lviv

\begin{tabular}{l|l|l} 
original article & UDC 577.352.315:612.33 & doi: 10.32718/ujvas4-2.01
\end{tabular}

Volume 4

Number 2

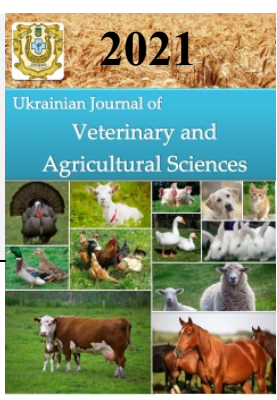

\title{
The enzyme activity dynamic relationship with the content of structural polypeptides of enterocyte membranes in cattle fetal
}

\author{
D. M. Masiuk
}

Dnipro State Agrarian and Economic University, Serhii Efremov Str., 25, Dnipro, 49600, Ukraine

\begin{tabular}{|c|c|}
\hline \multicolumn{2}{|l|}{$\begin{array}{l}\text { Article info } \\
\text { Received 01.04.2021 } \\
\text { Received in revised form } \\
\quad 03.05 .2021 \\
\text { Accepted } 04.05 .2021\end{array}$} \\
\hline \multicolumn{2}{|l|}{$\begin{array}{l}\text { Correspondence author } \\
\text { Dmytro Masiuk } \\
\text { Tel.: +38-050-636-62-37 } \\
\text { E-mail: dimasiuk@gmail.com }\end{array}$} \\
\hline \multicolumn{2}{|c|}{$\begin{array}{l}2021 \text { Masiuk D. M. This is an open- } \\
\text { access article distributed under the } \\
\text { terms of the Creative Commons } \\
\text { Attribution License, which permits } \\
\text { unrestricted use, distribution, and } \\
\text { reproduction in any medium, } \\
\text { provided the original author and } \\
\text { source are credited. }\end{array}$} \\
\hline \multicolumn{2}{|l|}{$(\mathrm{cc}) \mathrm{Br}$} \\
\hline \multicolumn{2}{|l|}{ Contents } \\
\hline 1. Introduction ................... & 3 \\
\hline 2. Materials and methods ....... & 4 \\
\hline 3. Results and discussion ....... & 4 \\
\hline 4. Conclusions ................ & 6 \\
\hline References ..................... & 6 \\
\hline
\end{tabular}

\begin{abstract}
The article performs new data on the relationship between the hydrolytic and transport enzyme activity at different poles of the enterocytes plasmolemma of cow's fetal large intestine with the content of individual fractions of polypeptides. An expressive direct dependence of enzyme activity dynamics on the apical and basolateral membranes of enterocytes containing low molecular weight proteins and an inverse relationship with the concentration of proteins with medium and large molecular weights has been proved. It was found that the alkaline activity of the phosphatase and $\gamma$-glutamyltransferase on the apical domain of enterocyte plasmolemma is directly related to the proteins content with molecular masses of 9.6-14.2 kD, $21 \mathrm{kD}, 22.5 \mathrm{kD}, 26 \mathrm{kD}, 33 \mathrm{kD}, 35 \mathrm{kD}, 170-185 \mathrm{kD}$, and $205 \mathrm{kD}(\mathrm{P} \leq 0.05-0.001)$. Gamma-glutamyltransferase activity is straightly related to protein quantity with molecular weights of $15.5 \mathrm{kDa}$ and $39 \mathrm{kD}(\mathrm{P} \leq 0.05)$. In contrast, alkaline phosphatase and GGT activity have inverse correlations with the content of polypeptides with molecular masses of $46 \mathrm{kD}, 63 \mathrm{kD}$, and $250 \mathrm{kD}$ in the apical membrane of enterocytes $(\mathrm{P} \leq 0.01-0.001)$. The lactase activity in the cattle enterocytes apical membrane during the test period has significant direct correlations only with the amount of the polypeptide of polypeptides with molecular weights of $31 \mathrm{kD}, 39 \mathrm{kD}$, and $100 \mathrm{kD}(\mathrm{P} \leq 0.05-0.01)$ and inverse relationships containing proteins with molecular masses of $46 \mathrm{kD}$ and $120 \mathrm{kD}(\mathrm{P} \leq 0.05)$. A linear dependence of the different ATPase activity of the apical membrane of red blood cells containing proteins with molecular weights of 9.6-14.2 $\mathrm{kD}, 15.5 \mathrm{kD}$, $21 \mathrm{kD}, 22.5 \mathrm{kD}, 33 \mathrm{kD}, 35 \mathrm{kD}, 39 \mathrm{kD}$, and $205 \mathrm{kD}(\mathrm{P} \leq 0.05-0.001)$ was observed. Alkaline phosphatase activity in the apical membrane of enterocytes is only directly related to the number of proteins with molecular weights of $17 \mathrm{kD}$ and $24 \mathrm{kD}(\mathrm{P} \leq 0.001)$ in this domain. It inversely depends on the content of proteins with molecular masses of 9.6-14.2 kD and $52 \mathrm{kD}(\mathrm{P} \leq 0.001)$. G-glutamyltransferase activity is inversely related to protein content with molecular weights of $43 \mathrm{kD}, 52 \mathrm{kD}, 66 \mathrm{kD}, 87 \mathrm{kD}$, and $100 \mathrm{kD}$ and $155 \mathrm{kD}(\mathrm{P} \leq 0.001)$. The $\mathrm{Ca}^{2+}, \mathrm{Mg}^{2+}$-ATPase of the basolateral membrane activity of enterocytes is directly related to the protein amount with molecular weights of $26 \mathrm{kD}(\mathrm{P} \leq 0.01), \mathrm{Mg}^{2+}$-ATPase and $\mathrm{Mg}^{2+}$-ATPase with protein content with the molecular value of $100 \mathrm{kD}(\mathrm{P} \leq 0.05)$.
\end{abstract}

Key words: fetus, cattle, enterocytes, jejunum, polypeptide composition.

\section{Citation:}

Masiuk, D. M. (2021). The enzyme activity dynamic relationship with the content of structural polypeptides of enterocyte membranes in cattle fetal. Ukrainian Journal of Veterinary and Agricultural Sciences, 4(2), 3-6.

\section{Introduction}

Polypeptides are the main structural and functional components of the membranes of the enterocytes plasmolemma. They provide transport function, nutrient secretion, reception, and regulation of cellular metabolism and membrane hydrolysis (Tarabova et al., 2016). The polypeptide composition of enterocyte plasmolemma depends on many factors (feeding, age, species, physiological condition, etc.) It has been proved that during the fertile period, there are dynamic changes in the polypeptide structure of enterocyte membranes in cattle (Filho et al., 2016). They indicate the functional role of different domains (Tilney et al., 1973). Features of the polypeptide composition of enterocytes are explained by different types of nutrition (Havrylin \& Masiuk, 2004).
Information on the patterns of the structural and functional organization of plasma membranes of red blood cells during fetal development is incomplete and few (Valadão et al., 2018). The data on the connection between the enzymes of apical and basolateral enterocytes membrane activity in cows structural proteins are missing in these domains. Disclosure of these features will make it possible to determine the general patterns of their formation in prenatal ontogenesis and the specifics of individual elements responsible for the formation of adaptive interaction with biologically active components of colostrum.

Membrane enzymes of the small intestine provide transepithelial transfer (Saakes et al., 2018). The need of cells is to maintain ionic homeostasis and contractile activity. Different adenosine triphosphatases have various functions and quantitative parameters in some areas of enterocyte plasmolemma (Panizza et al., 2019). Regularities 
of adenosine triphosphatase activity are primarily studied in laboratory animals (Apell, 2018). Therefore, the research of the connection between the dynamics of the activity of membrane-bound enzymes of enterocytes with the polypeptide composition allows us to form a fair idea of the specifics of prenatal formation of parietal digestion and absorption of feed nutrients.

\section{Materials and methods}

The research was carried out on the fetus of Holstein cattle, aged 2-9 months. Material for the study was obtained from 80 clinically healthy cows during forced slaughter. Determination of fetal age was performed according to the method described by Studentsov A.P. Samples of tissues of the jejunum were taken by anatomical preparation. Isolation of intestinal cells was perpetrated by the author's modification of Tomchuk V. A. (Patent for utility model № 118136 Ukraine. The method of obtaining isolated enterocytes of cows). To obtain apical and basolateral membranes from a suspension of isolated enterocytes of the large intestine of cattle, a modified differential centrifugation method was applied (Patent for utility model № 118133. Method of fractionation plasma membranes of isolated enterocytes). In the apical and basolateral membranes, the activity of: alkaline phosphatase (APh 3.1.3.1.) was determined by the method of Garen-Leventhal; $\gamma$-glutamyl transferase (EC 2.3.2.2.), lactase (EC 3.2.1.23.), $\mathrm{Na}^{+}, \mathrm{K}^{+}$-ATPase (EC 3.6.3.9), $\mathrm{Ca}^{2+}$,
$\mathrm{Mg}^{2+}$-ATPase (EC 3.6.1.3) and $\mathrm{Mg}^{2+}$-ATPase (EC 3.6.3.2) according to Boldyrev's recommendations. Statistical analysis of the results was performed by calculating the correlation coefficient by the Pearson method.

\section{Results and discussion}

According to the results of our research, it is established that the functional activity of membrane hydrolases in cattle enterocytes in the fetal period of ontogenesis is specific for each macrodomain of plasmolemma, and its dynamics tend to gradually decrease by the time of calf birth. The transport ATPase activity of the enterocyte membrane of the large intestine of cows in the early fertile period of ontogenesis gradually declines with higher action on the basolateral membrane. The peak of this activity occurs in the seventh month of fetal development. The linearity and interdependence of the development of enzyme systems through the intensive proliferation of small intestinal epitheliocytes have been proved. The transport ATPasesa activity on different plasma membrane domains is significantly related $(\mathrm{P}<0.01-0.001)$.

The obtained results indicate that in the early fetus period in the enterocytes plasmolemma of the cattle large intestine in the apical and basolateral membranes are represented respectively 27 and 25 protein fractions with molecular weights from 9.6 to $300 \mathrm{kD}$.

Table 1

Correlation of enzyme activity with molecular weights of apical membrane proteins of cattle enterocytes, $r(n=6)$

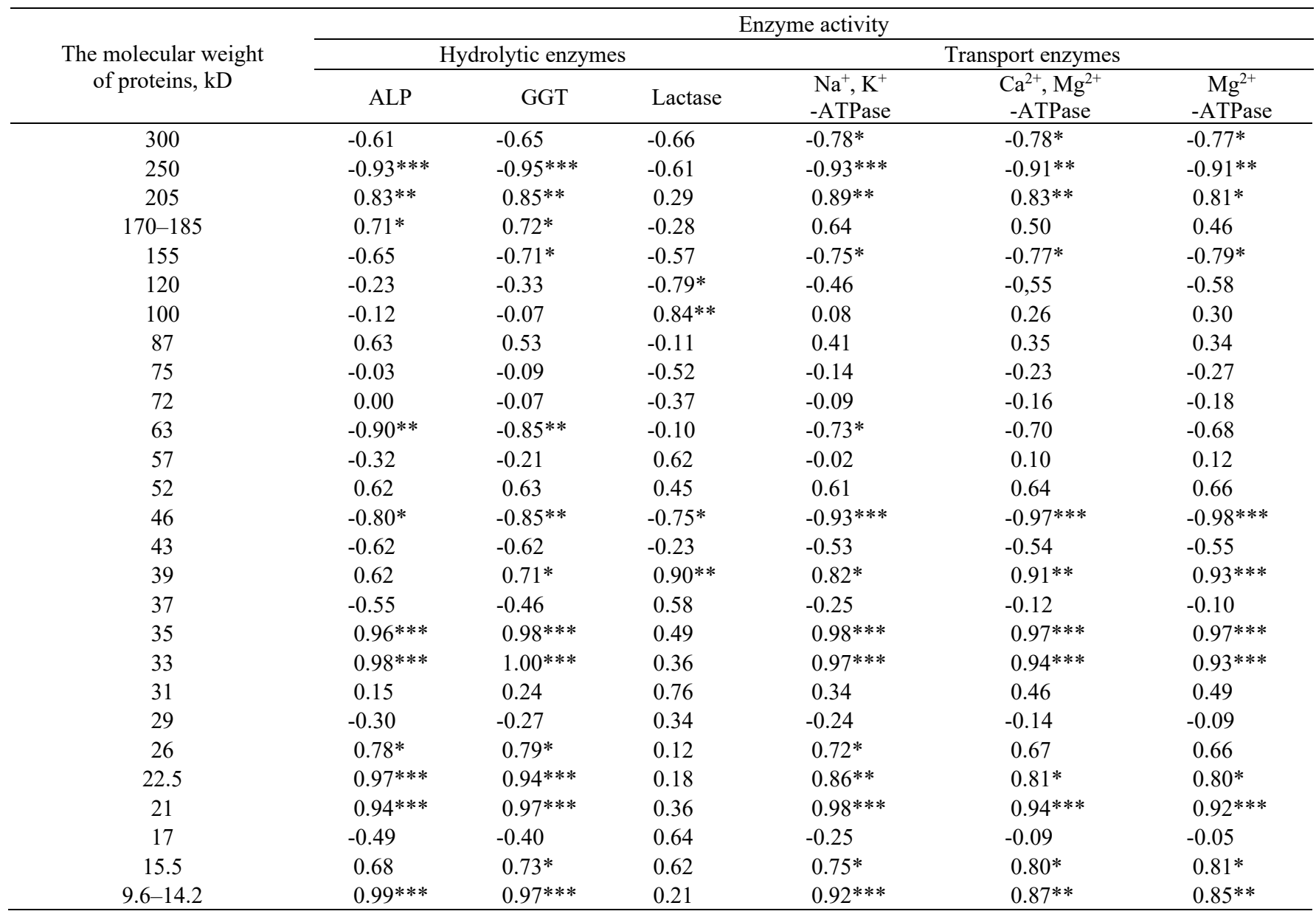

Notes: $*-\mathrm{P} \leq 0.05 ; * *-\mathrm{P} \leq 0.01 ; * * *-\mathrm{P} \leq 0.001$ 
It was found that the alkaline phosphatase and $\gamma$ glutamyltransferase activity on the apical domain of enterocyte plasmolemma is directly related to the content of proteins with molecular masses of 9.6-14.2 kD ( $\mathrm{r}=0.97-0.99$; $\mathrm{P} \leq 0.001), 21 \mathrm{kD}$ and $22.5 \mathrm{kD}(\mathrm{r}=0.94-0.97 ; \mathrm{P} \leq 0.001)$, $26 \mathrm{kD}(\mathrm{r}=0.78-0.79 ; \mathrm{P} \leq 0.05), 33 \mathrm{kD}$ and $35 \mathrm{kD}(\mathrm{r}=0.96-$ $1.00 ; \mathrm{P} \leq 0.001), 170-185 \mathrm{kD}(\mathrm{r}=0.71-0.72 ; \mathrm{P} \leq 0.05)$ and $205 \mathrm{kD}(\mathrm{r}=0.83-0.85 ; \mathrm{P} \leq 0.01)$. In addition, gammaglutamyltransferase activity is directly related to protein content with molecular weights of $15.5 \mathrm{kD}$ and $39 \mathrm{kD}(\mathrm{r}=0.71-$ $0.73 ; \mathrm{P} \leq 0.05)$. In contrast, alkaline phosphatase and GGT activity have inverse correlations with the content of polypeptides with molecular masses of $46 \mathrm{kD}(\mathrm{r}=-0.97-0.99$; $\mathrm{P} \leq 0.001), 63 \mathrm{kD}$ in the apical membrane of enterocyte cells. 0.85-0.90; $\mathrm{P} \leq 0.01-0.001)$ and $250 \mathrm{kD}(\mathrm{r}=-0.93-$ $0.95 ; \mathrm{P} \leq 0.001$ ). However, only $\gamma$-glutamyltransferase activity has significant inverse correlations with the content of polypeptides with a molecular weight of $155 \mathrm{kD}$ (Table 1).

It should be noted that the lactase activity lactase in the apical membrane of enterocytes of cattle during the experimental period has significant direct correlations only with the content of polypeptides with molecular weights of $31 \mathrm{kD}$ $(\mathrm{r}=0.76 ; \mathrm{P} \leq 0.05), 39 \mathrm{kD}(\mathrm{r}=0.90 ; \mathrm{P} \leq 0.01)$ and $100 \mathrm{kD}$ $(\mathrm{r}=0.84 ; \mathrm{P} \leq 0.01)$ and inverse connect with protein format with molecular amount of $46 \mathrm{kD}(\mathrm{r}=-0.75 ; \mathrm{P} \leq 0.05)$ and $120 \mathrm{kD}(\mathrm{r}=-0.79 ; \mathrm{P} \leq 0.05)$.

The general patterns of connections between the transport enzymes activity in the apical membrane of enterocytes of the large intestine of cattle with individual protein fractions were the same as in hydrolytic enzymes, but some features were found. We note a direct dependence of the activity of different ATPases of the apical membrane of enterocytes with the format of proteins with molecular masses of 9.6-14.2 kD ( $\mathrm{r}=0.87-0.92 ; \mathrm{P} \leq 0.01-0.001)$, $15.5 \mathrm{kD}(\mathrm{r}=0.75-0.81 ; \mathrm{P} \leq 0.05-0.01), 21 \mathrm{kD}(\mathrm{r}=0.92-$ $0.98 ; \mathrm{P} \leq 0.001), 22.5 \mathrm{kD}(\mathrm{r}=0.80-0.86 ; \mathrm{P} \leq 0.05-0.01)$, $33 \mathrm{kD}$ and $35 \mathrm{kD}(\mathrm{r}=0.93-0.98 ; \mathrm{P} \leq 0.001), 39 \mathrm{kD}$ $(\mathrm{r}=0.82-0.93 ; \mathrm{P} \leq 0.01-0.001)$ and $205 \mathrm{kD}(\mathrm{r}=0.81-0.89$; $\mathrm{P} \leq 0.05-0.01)$. In addition, the activity of $\mathrm{Na}^{+}, \mathrm{K}^{+}$-ATPase of the apical membrane of fetal enterocytes is directly related to the content of proteins with a molecular weight of $26 \mathrm{kD}(\mathrm{r}=0.72 ; \mathrm{P} \leq 0.05)$.

The $\mathrm{Na}^{+}, \mathrm{K}^{+}$-ATPase, $\mathrm{Ca}^{2+}, \mathrm{Mg}^{2+}$-ATPase and $\mathrm{Mg}^{2+}$ ATPase activities have inverse correlations with the content in the apical membrane of polypeptides with molecular masses of $46 \mathrm{kD}(\mathrm{r}=-0.93-0.98 ; \mathrm{P} \leq 0.001), 155 \mathrm{kD}(\mathrm{r}=-0.75-0.79$; $\mathrm{P} \leq 0.05), 250 \mathrm{kD}(\mathrm{r}=-0.91-0.93 ; \mathrm{P} \leq 0.01-0.001)$ and $300 \mathrm{kD}(\mathrm{r}=-0.77-0.78 ; \mathrm{P} \leq 0.05)$. However, only $\mathrm{Na}^{+}, \mathrm{K}^{+}-$ ATPase activity has significant opposite correlations with the content of polypeptides with a molecular weight of $63 \mathrm{kDa}$ $(\mathrm{r}=-0.73 ; \mathrm{P} \leq 0.05)$. Apical membrane proteins with molecular amount of $17 \mathrm{kD}, 29 \mathrm{kD}, 37 \mathrm{kD}, 43 \mathrm{kD}, 52 \mathrm{kD}, 57 \mathrm{kD}$, $75 \mathrm{kD}$, and $87 \mathrm{kD}$ do not have significant correlations with the activity of hydrolytic and transport enzymes.

The hydrolytic and transport enzyme activity in the basolateral membrane of the enterocytes of the cattle large intestine has distinctive links with the content of different fractions of proteins from those in the apical membrane. Thus, the alkaline phosphatase activity in the enterocytes apical membrane is only directly related to the content in this domain of proteins with a molecular amount of $17 \mathrm{kD}$ $(\mathrm{r}=0.95 ; \mathrm{P} \leq 0.001)$ and $24 \mathrm{kD}(\mathrm{r}=0.98 ; \mathrm{P} \leq 0.001)$ and inversely depends on the content of them with the molecular format of $9.6-14.2 \mathrm{kD}(\mathrm{r}=-0.83 ; \mathrm{P} \leq 0.01)$ and $52 \mathrm{kD}$ $(\mathrm{r}=-0.92 ; \mathrm{P} \leq 0.001)$. Lactase activity on the apical membrane of enterocytes is directly related to the content of proteins with molecular masses of 9.6-14.2 kDa, $22.5 \mathrm{kD}$, and $57 \mathrm{kD}(\mathrm{r}=0.80-0.88 ; \mathrm{P} \leq 0.05-0,01)$ and has inverse correlations with the protein content with molecular weights of $43 \mathrm{kD}(\mathrm{r}=-0.89 ; \mathrm{P} \leq 0.01)$ and $155 \mathrm{kD}(\mathrm{r}=-0.84 ; \mathrm{P} \leq 0.01)$.

The activity of $\gamma$-glutamyltransferase in the apical membrane of enterocytes has much stronger correlations with the content of individual protein fractions in this domain of enterocytes. In particular, the activity of this enzyme is directly related to the content in the apical membrane of enterocytes of proteins with molecular weights of $17 \mathrm{kDa}$ $(\mathrm{r}=0.93 ; \mathrm{P} \leq 0.001), 22.5 \mathrm{kD}(\mathrm{r}=0.92 ; \mathrm{P} \leq 0.001), 24 \mathrm{kD}$, $26 \mathrm{kD}$ and $29 \mathrm{kD}(\mathrm{r}=0.86-0.88 ; \mathrm{P} \leq 0.01), 33 \mathrm{kD}(\mathrm{r}=0.91$; $\mathrm{P} \leq 0.01)$ and $57 \mathrm{kD}(\mathrm{r}=0.71 ; \mathrm{P} \leq 0.05)$. In addition, the activity of $\gamma$-glutamyltransferase is oppositly related to the protein content with molecular weights of $43 \mathrm{kD}(\mathrm{r}=-0.72$; $\mathrm{P} \leq 0.05), 52 \mathrm{kD}(\mathrm{r}=-0.94 ; \mathrm{P} \leq 0.001), 66 \mathrm{kD}(\mathrm{r}=-0.82$; $\mathrm{P} \leq 0.05), 87 \mathrm{kD}$ and $100 \mathrm{kD}(\mathrm{r}=-0.73 ; \mathrm{P} \leq 0.05)$ and $155 \mathrm{kD}(\mathrm{r}=-0.94 ; \mathrm{P} \leq 0.001)$.

The transport enzymes activity of the basolateral membrane of enterocytes has stable functional links with the content of individual fractions of proteins in this domain (Table 2). Note the direct correlations between the activity of ATPases with protein amount of molecular weights of $39 \mathrm{kD}$ and $35 \mathrm{kD}(\mathrm{r}=0.73-0.97 ; \mathrm{P} \leq 0.05-0.001), 46 \mathrm{kD}$ $(\mathrm{r}=0.73-0.92 ; \mathrm{P} \leq 0.05-0.001), 63 \mathrm{kD}, 66 \mathrm{kD}, 72 \mathrm{kD}$ and $87 \mathrm{kD}(\mathrm{r}=0.77-0.94 ; \mathrm{P} \leq 0.05-0.001)$ and $155 \mathrm{kD}$ $(\mathrm{r}=0.72-0.86, \mathrm{P} \leq 0.05-0.01)$. In addition, the activity of $\mathrm{Ca}^{2+}, \mathrm{Mg}^{2+}$-ATPase of the basolateral membrane of enterocytes is directly related to the content of proteins with molecular masses of $26 \mathrm{kD}(\mathrm{r}=0.80 ; \mathrm{P} \leq 0.01), \mathrm{Mg}^{2+}$-ATPase and $\mathrm{Mg}^{2+}$-ATPase -with protein quantity with molecular weights of $100 \mathrm{kD}(\mathrm{r}=0.81 ; \mathrm{P} \leq 0.05)$, and $\mathrm{Na}^{+}, \mathrm{K}^{+}$-ATPase and $\mathrm{Mg}^{2+}$-ATPase - with protein content with molecular masses of $52 \mathrm{kD}(\mathrm{r}=0.75-0.79 ; \mathrm{P} \leq 0.05)$.

Accordingly, the $\mathrm{Na}^{+}, \mathrm{K}^{+}$-ATPase, $\mathrm{Ca}^{2+}, \mathrm{Mg}^{2+}$-ATPase and $\mathrm{Mg}^{2+}$-ATPase activity has opposite correlations with the content in the basolateral membrane of polypeptides with molecular weights of $19 \mathrm{kD}(\mathrm{r}=-0.75-0.89 ; \mathrm{P} \leq 0.05-0.01)$, $21 \mathrm{kD}(\mathrm{r}=-0.91-0.97 ; \mathrm{P} \leq 0.01-0.001)$ and $22.5 \mathrm{kD}(\mathrm{r}=-$ $0.79-0.91 ; \mathrm{P} \leq 0.05-0.01)$. In addition, only the $\mathrm{Ca}^{2+}, \mathrm{Mg}^{2+}-$ ATPase activity has significant inverse correlations with the amount of polypeptides with a molecular mass of 9.6$14.2 \mathrm{kD}(\mathrm{r}=-0.93 ; \mathrm{P} \leq 0.01)$. The $\mathrm{Na}+, \mathrm{K}+$-ATPase and $\mathrm{Mg}^{2}{ }^{+}$-ATPase activity has opposite interrelation with the content of proteins with molecular weights of $17 \mathrm{kD}$ $(\mathrm{r}=-0.81-0.84 ; \mathrm{P} \leq 0.01)$ and $26 \mathrm{kD}(\mathrm{r}=-0.79-0.90$; $\mathrm{P} \leq 0.05-0.01$, while the $\mathrm{Na}^{+}, \mathrm{K}^{+}$-ATPase activity is inversely related to the scope of polypeptides with a molecular mass of $120 \mathrm{kD}(\mathrm{r}=-0.79 ; \mathrm{P} \leq 0.01)$.

Thus, we found reliable connections between the hydrolytic and transport enzyme activity with the concentration of individual polypeptides at different poles of enterocytes. Significantly expanded the available data on the peculiarities of protein metabolism in plasma enterocytes of the cattle large intestine from two to nine months of age. The activity of the enzymes studied by us at different poles of enterocyte plasmalemma is, to a greater extent, directly related to polypeptide fractions from $9.6 \mathrm{kD}$ to $39 \mathrm{kD}$ and, conversely, to proteins with molecular weights from $46 \mathrm{kD}$ to $300 \mathrm{kD}$. In addition, the enzyme activity is more correlated with another fraction of proteins of the basolateral membrane compared to the apical membrane of enterocytes. 
Table 2

Correlation of enzyme activity with molecular weights of proteins of the basolateral membrane of cattle enterocytes, $r(n=6)$

\begin{tabular}{|c|c|c|c|c|c|c|}
\hline \multirow{3}{*}{$\begin{array}{c}\text { The molecular weight } \\
\text { of proteins, } \mathrm{kD}\end{array}$} & \multicolumn{6}{|c|}{ Enzyme activity } \\
\hline & \multicolumn{3}{|c|}{ Hydrolytic enzymes } & \multicolumn{3}{|c|}{ Transport enzymes } \\
\hline & ALP & GGT & Lactase & $\mathrm{Na}^{+}, \mathrm{K}^{+}$-ATPase & $\mathrm{Ca}^{2+}, \mathrm{Mg}^{2+}$-ATPase & $\mathrm{Mg}^{2+}-\mathrm{ATPase}$ \\
\hline 155 & -0.61 & $-0.94 * * *$ & $-0.84 * *$ & $0.72 *$ & $0.80 *$ & $0.86 * *$ \\
\hline 120 & 0.61 & 0.33 & -0.50 & $-0.79 * *$ & -0.51 & -0.65 \\
\hline 100 & -0.39 & $-0.73^{*}$ & -0.70 & 0.70 & $0.81 *$ & $0.81 *$ \\
\hline 87 & -0.46 & $-0.73 *$ & -0.59 & $0.86 * *$ & $0.94 * * *$ & $0.94 * * *$ \\
\hline 72 & -0.35 & -0.60 & -0.63 & $0.79 *$ & $0.89 * *$ & $0.87 * *$ \\
\hline 66 & -0.54 & $-0.82 *$ & -0.66 & $0.77 *$ & $0.82 *$ & $0.88 * *$ \\
\hline 63 & -0.18 & -0.26 & -0.23 & $0.82 *$ & $0.89 * *$ & $0.79 *$ \\
\hline 57 & 0.30 & $0.71 *$ & $0.88 * *$ & -0.35 & -0.51 & -0.54 \\
\hline 52 & $-0.92 * * *$ & $-0.94 * * *$ & -0.15 & $0.75^{*}$ & 0.52 & $0.79^{*}$ \\
\hline 46 & -0.64 & -0.50 & 0.24 & $0.92 * * *$ & $0.73 *$ & $0.83 * *$ \\
\hline 43 & -0.30 & $-0.72 *$ & $-0.89 * *$ & 0.42 & 0.59 & 0.60 \\
\hline 39 & -0.13 & -0.45 & -0.68 & $0.73 *$ & $0.93 * * *$ & $0.80^{*}$ \\
\hline 35 & -0.52 & -0.63 & -0.22 & $0.97 * * *$ & $0.96 * * *$ & $0.97 * * *$ \\
\hline 33 & 0.70 & $0.91 * *$ & 0.47 & $-0.85 * *$ & $-0.82 *$ & $-0.94 * * *$ \\
\hline 31 & 0.47 & 0.68 & 0.46 & $-0.90 * *$ & $-0.95 * * *$ & $-0.95 * * *$ \\
\hline 29 & 0.59 & $0.88 * *$ & 0.61 & -0.54 & -0.53 & -0.67 \\
\hline 26 & 0.62 & $0.86^{* *}$ & 0.59 & $-0.79 *$ & $-0.80 *$ & $-0.90 * *$ \\
\hline 24 & $0.98 * * *$ & $0.87 * *$ & -0.13 & $-0.74 *$ & -0.42 & $-0.73 *$ \\
\hline 22.5 & 0.56 & $0.92 * * *$ & $0.80 *$ & $-0.79 *$ & $-0.88 * *$ & $-0.91 * *$ \\
\hline 21 & 0.59 & 0.70 & 0.28 & $-0.96 * * *$ & $-0.91 * *$ & $-0.97 * * *$ \\
\hline 19 & 0.35 & 0.70 & 0.69 & $-0.75^{*}$ & $-0.89 * *$ & $-0.86 * *$ \\
\hline 17 & $0.95 * * *$ & $0.93 * * *$ & 0.08 & $-0.81 *$ & -0.57 & $-0.84^{*}$ \\
\hline 15.5 & 0.63 & 0.31 & -0.70 & -0.10 & 0.29 & -0.01 \\
\hline $9.6-14.2$ & $-0.83 * *$ & -0.70 & $0.80 *$ & 0.04 & $-0.93 * * *$ & -0.10 \\
\hline
\end{tabular}

Notes: $*-\mathrm{P} \leq 0.05 ; * *-\mathrm{P} \leq 0.01 ; * * *-\mathrm{P} \leq 0.001$

\section{Conclusions}

Based on the obtained results, we established new scientific data on the relationship between hydrolytic and transport enzymes at different poles of the enterocytes plasmolemma of the cattle large intestine with the content of individual fractions polypeptides. A clear, direct dependence of enzyme activity dynamics on enterocytes' apical and basolateral membranes containing low molecular weight proteins and an inverse relationship with the concentration of proteins with medium and giant molecular masses has been proved.

Prospects for further research. Prospects for further research lie in the established features of the processes of membrane hydrolysis, transport, secretion of substances in the intestinal tract of ruminants in prenatal ontogenesis.

\section{References}

Apell, H. J. (2018). Finding Na, K-ATPase: I-From Cell to Molecule. Substantia, 2(1), 17-28. doi: 10.13128/Substantia-38.

Filho, N., Carlos, L. et al. (2016). Use of the enzyme gammaglutamyl transferase (GGT) as an indirect measure of passive transfer of immunity in holstein calves and association with the occurrence of diarrhea after birth. Bioscience Journal, 32(1), 455-459. doi: 10.14393/BJ-v32n2a2016-29476.

Havrylin, P. M., \& Masiuk, D. M. (2004). Zakonomirnosti morfohenezu tkanynnykh komponentiv orhaniv krovotvorennia ta imunnoho zakhystu u teliat. Naukovyi visnyk Lvivskoho natsionalnoho universytetu veterynarnoi medytsyny ta biotekhnolohii im. S. Z. Gzhytskoho. Seriia: Veterynarna medytsyna, 6(1), 16-25 (in Ukrainian).

Masiuk, D. M. (2020). Interconnection between the expression of fc- $\gamma$-receptor proteins and the activity of enzymes in the empty intestine plasmolema of the empty intestine of the great horny skin. Ukrainian Chasopis of Veterinary Sciences, 11(1), 70-80.

Panizza, E., Zhang, L., Fontana, J. M., Hamada, K. et al. (2019). Ouabain Regulated Phosphoproteome Reveals Molecular Mechanisms Behind Na, K-ATPase Control of Cell Adhesion, Proliferation and Survival. The FASEB Journal, 33(9), 1019310206. doi: 10.1096/fj.201900445R.

Saakes, M., Hamelers, H. V. M., \& Van Egmond, W. J. (2018). Method for Operating of a Regenerative Bipolar Membrane Fuel Cell, and Regenerative Bipolar Membrane Fuel Cell There. 15556887.

St Johnston, D. I., \& Sanson, B. (2011). Epithelial polarity and morphogenesis. Curr Opin Cell Biol., 23(5), 540-546. doi: 10.1016/j.ceb.2011.07.005.

Tarabova, L., Makova Z., Piesova, E., Szaboova, R., \& Faixova, Z. (2016). Intestinal mucus layer and mucins (a review). Folia Veterinaria, 60(1), 21-25. doi: 10.1515/fv-2016-0003.

Tilney, L. G., Hatano, S., Ishikawa, H., \& Mooseker, M. S. (1973). The polymerization of actin: its role in the generation of the acrosomal process of certain echinoderm sperm. J. Cell Biol, 59(1), 109-126. doi: 10.1083/jcb.59.1.109.

Valadão, L., Da Silva, H. M., \& Da Silva, F. M. (2018). Bovine Embryonic Development to Implantation. Embryogenesis. IntechOpen. doi: 10.5772/intechopen.80655. 